\title{
Reduced endoplasmic reticulum luminal calcium links saturated fatty acid-mediated endoplasmic reticulum stress and cell death in liver cells
}

Yuren Wei · Dong Wang · Christopher L. Gentile •

Michael J. Pagliassotti

Published online: 11 July 2009

(C) Springer Science+Business Media, LLC. 2009

Erratum to: Mol Cell Biochem

DOI 10.1007/s11010-009-0142-1

In the original article Fig. 2 is not displayed correctly. To put matters right we are now reprinting Fig. 2 as it should have appeared. Everything else in the paper remains correct.

The online version of the original article can be found under doi: 10.1007/s11010-009-0142-1.

Y. Wei · D. Wang · C. L. Gentile · M. J. Pagliassotti ( $\square)$

Department of Food Science and Human Nutrition,

Colorado State University, Gifford 234, Fort Collins,

CO 80523-1571, USA

e-mail:pagliasm@cahs.colostate.edu 
Fig. 2 Induction of ER stress and cell death by thapsigargin and palmitate in primary hepatocytes. Rat primary hepatocytes were incubated for 6 or $16 \mathrm{~h}$ in control media (LG), or control media supplemented with thapsigargin (Thap, $450 \mathrm{nM})$, oleate $(\mathrm{O}, 250 \mu \mathrm{M})$, or palmitate $(\mathrm{P}, 250 \mu \mathrm{M})$. a Real time PCR analysis of glucose-regulated protein 78 (GRP78), growth arrest and

DNA damage-inducible gene 34 (GADD34), activating transcription factor 4 (ATF4), and CCAAT/enhancer-binding protein homologous protein (CHOP). Data from LG were set to 1 . b Western blot analysis of GRP78, CHOP, and actin (loading control) proteins. The gels shown are representative of five independent experiments and data in graphs are expressed as the ratio of the target protein to actin. c ELISA-based cell death and MTT viability assay. Data in graphs are reported as the mean \pm SD of triplicate samples from 5 independent experiments. *Significantly $(P<0.05)$ different from LG and $\mathrm{O} 250$
A

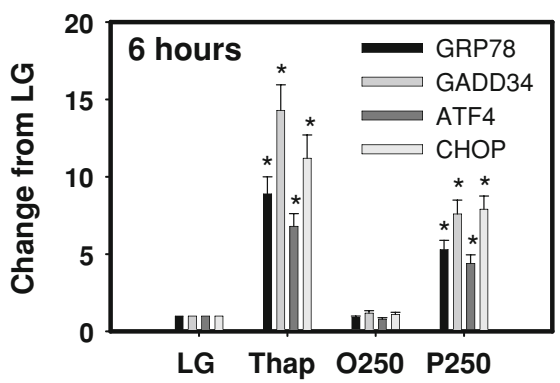

B
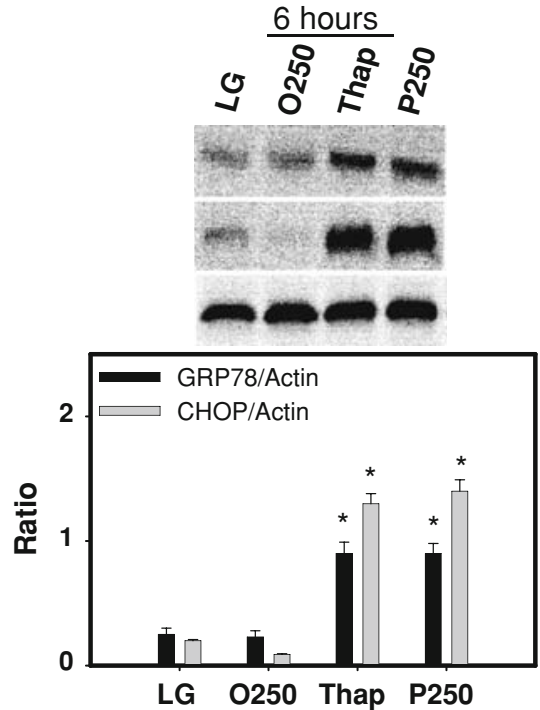

C
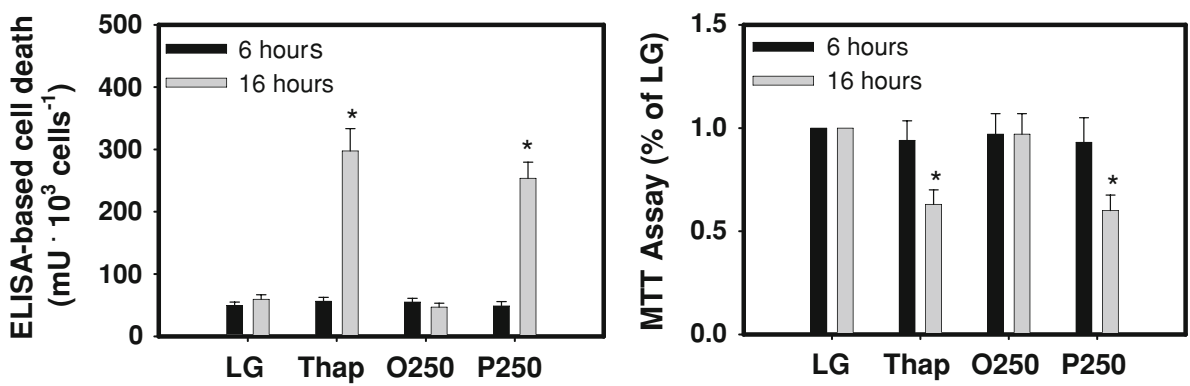